Mean Girl 


\section{AMERICAN STUDIES NOW:}

\section{CRITICAL HISTORIES OF THE PRESENT}

\section{Edited by Lisa Duggan and Curtis Marez}

Much of the most exciting contemporary work in American Studies refuses the distinction between politics and culture, focusing on historical cultures of power and protest, on the one hand, or the political meanings and consequences of cultural practices, on the other. American Studies Now offers concise, accessible, authoritative, e-first books on significant political debates, personalities, and popular cultural phenomena quickly, while such teachable moments are at the forefront of public consciousness.

I. We Demand: The University and Student Protests, by Roderick A. Ferguson

2. The Fifty-Year Rebellion: How the U.S. Political Crisis Began in Detroit, by Scott Kurashige

3. Trans: A Quick and Quirky Account of Gender Variability, by Jack Halberstam

4. Boycott! The Academy and Fustice for Palestine, by Sunaina Maira

5. Imagining the Future of Climate Change: World-Making through Science Fiction and Activism, by Shelley Streeby

6. Making All Black Lives Matter: Reimagining Freedom in the Twenty-First Century, by Barbara Ransby

7. Beyond the Pink Tide: Art and Political Undercurrents in the Americas, by Macarena Gómez-Barris

8. Mean Girl: Ayn Rand and the Culture of Greed, by Lisa Duggan 


\title{
Mean Girl
}

Ayn Rand and the Culture of Greed

\author{
Lisa Duggan
}

\section{마}


University of California Press, one of the most distinguished university presses in the United States, enriches lives around the world by advancing scholarship in the humanities, social sciences, and natural sciences. Its activities are supported by the UC Press Foundation and by philanthropic contributions from individuals and institutions. For more information, visit www.ucpress.edu.

University of California Press

Oakland, California

(C) 2019 by Lisa Duggan

Library of Congress Cataloging-in-Publication Data

Names: Duggan, Lisa, 1954- author.

Title: Mean girl : Ayn Rand and the culture of greed / Lisa Duggan.

Description: Oakland, California : University of

California Press, [2019] | Includes bibliographical references.

Identifiers: LCCN 20I80510I4 (print) | LCCN 2018054695 (ebook) | ISBN 9780520967793 (ebook and ePDF) ISBN 9780520294769 (cloth : alk. paper) ISBN 9780520294776 (pbk. : alk. paper)

Subjects: LCSH: Rand, Ayn-Criticism and interpretation. | Rand, Ayn-Influence.

Classification: LCC PS3535.A547 (ebook) | LCC P\$3535.A547 Z63 2019 (print) | DDC $813 / .52$-dc23

LC record available at https://lccn.loc.gov/20180510I4

Manufactured in the United States of America

$\begin{array}{llllllll}26 & 25 & 24 & 23 & 22 & 21 & 20 & 19\end{array}$

$\begin{array}{llllllllll}\text { IO } & 9 & 8 & 7 & 6 & 5 & 4 & 3 & 2 & \text { I }\end{array}$ 